\title{
Potensi Tahfidz Al-Qur’an dalam Menumbuhkan Kecerdasan Spiritual
}

\author{
Miftakhul Huda \\ Program Studi Agama-Agama Fakultas Ushuluddin, UNIDA Gontor Kampus Siman \\ Email : maeskey19@gmail.com
}

\begin{abstract}
This study was written to examine how effectively memorizing the Qur'an in cultivating one's spiritual intelligence. The method used by researchers to study in this paper is a qualitative method with analytical studies that then produce some findings. First, cultivating spiritual intelligence is one of the methods to solve the problem of lack of morals these days. Second, the most effective way to cultivate one's spiritual intelligence is through memorization of the Qur'an because by memorizing the Qur'an a human being will always draw closer to God. Third, memorizing the Qur'an not only fosters spiritual intelligence but can also foster emotional and intellectual intelligence. Fourth, the memorization of the Qur'an will in fact be affected in their lifestyle, this is because often they mix with the verses of Allah SWT. So that the lifestyle, piker pattern, personality and even behavior will be very similar to what is written in the Qur'an. And fifth, the Qur'an is not only a medium that can be read by humans but the Qur'an can also be used as a treatment for some diseases in the human body.
\end{abstract}

Keywords : Spiritual Intelligence, Tahfidz Al-Qur'an, Memorizing the Qur'an

\begin{abstract}
Abstrak
Penelitian ini ditulis bertujuan untuk mengkaji bagaimana efektifitas menghafal al-Qur'an dalam menumbuhkan kecerdasan spiritual seseorang. Metode yang digunakan oleh peneliti untuk mengkaji dalam tulisan ini adalah metode kualitatif dengan studi analisis yang kemudian menghasilkan beberapa temuan. Pertama, menumbuhkan kecerdasan spiritual merupakan salah satu metode untuk menyelesaikan permasalahan minimnya moral belakangan ini. Kedua, cara yang paling efektif dalam untuk menumbuhkan kecerdasan spiritual seseorang ialah melalui hafalan al-Qur'an karena dengan menghafal al-Qur'an seorang manusia akan selalu mendekatkan diri kepada Allah. Ketiga, menghafal al-Qur'an tidak hanya menumbuhkan kecerdasan spiritual saja melainkan dapat menumbuhkan juga kecerdasan emosional dan intelektual. Keempat, para penghafal al-Qur'an pada hakikatnya akan terpengaruh dalam gaya kehidupan mereka, hal ini dikarenakan seringnya mereka bercampur dengan ayat-ayat Allah SWT. Sehingga pola hidup, pola piker, kepribadian dan bahkan tingkah lakunya akan sangat mirip seperti apa yang tertulis di dalam al-Qur'an. Dan kelima, al-Qur'an tidak hanya sebagai media yang bisa dibaca oleh manusia tetapi al-Qur'an juga dapat dijadikan sebagai pengobatan untuk beberapa penyakit dalam tubuh manusia.
\end{abstract}

Kata Kunci : Kecerdasan Spiritual, Tahfidz Al-Qur'an, Menghafal Al-Qur'an 


\section{Pendahuluan}

Al-Qur'an merupakan kalam Allah yang bernilai mukjizat, diturunkan kepada nabi besar Muhammad S.A.W. melalui perantara malaikat yaitu Jibril. Malaikat Jibril memiliki tugas berupa menyampaikan wahyu ${ }^{1}$ dari Allah dan mengajarkannya agar al-Qur'an dijadikan sebagai petunjuk dan pedoman hidup seluruh umat manusia. Bagi seseorang muslim, al-Qur'an merupakan salah-satu pegangan dan tuntutan hidup. Maka sering kali al-Qur'an dijadikan sebagai identitas umat muslim yang isinya dikenal, dimengerti, dan dihayati oleh setiap individu yang mengaku sebagai umat muslim. ${ }^{2}$

Allah telah menjamin akan keaslian dan kemurnian al-Qur'an itu sendiri sehingga alQur'an tidak dapat diragukan lagi, sebagaimana dalam firman-Nya yang artinya:

'Sesungguhnya kamilah yang menurunkan al-Qur'an dan sesungguhnya kami benarbenar memeliharanya. "(Q.S. Al-Hijr : 9). ${ }^{3}$

Hakikat al-Qur'an yang akan terus dijaga keasliaannya dan juga kemurniaannya menarik banyak kaum Barat. Mulai dengan beberapa dari mereka yang berupaya mengganti beberapa ayat dalam al-Qur'an. Masalah ini kerap muncul yang membuat keresahan umat muslim khususnya mereka yang awam terhadap kitab suci al-Qur'an. Oleh karena itu kegiatan menghafal al-Qur'an ini merupakan salah satu tradisi untuk mencegah permasalahan tersebut. ${ }^{4}$

Usaha untuk menjaga kemurnian al-Qur'an salah-satunya adalah dengan menghafalkannya. Banyaknya hadits Rasulullah yang menungkapkan keagungan bagi orang yang menhafal al-Qur'an. Bahkan bagi mereka yang menghafalkan al-Qur'an dengan niatan kepada Allah atau sering disebut sebagai tahfidz memiliki tempat yang telah disediakan oleh Allah dan ditempatkan bersama dengan nabi di surga kelak. ${ }^{5}$

Menghafal al-Qur'an merupakan suatu proses mengingat, dimana seluruh materi ayat berupa rincian lainnya seperti fonetik, waqaf, dan lain-lain. ${ }^{6}$ Dengan menghafal al-Qur'an sesorang dipermudah dalam memahami dan mengingat isi-isi al-Qur'an dan juga menjaga keontentikannya serta dapat menjadi sebuah amal ibadah. Dalam menghafal al-Qur'an

\footnotetext{
${ }^{1}$ Yusuf Qandhawi, Berinteraksi dengan Al-Qur'an, (Jakarta : Gema Insani Press, 1999), 25.

${ }^{2}$ Lisya Chairoani dan Subandi, Psikologi Santri Menghafal Al-Qur'an: Peran Regulasi Diri, (Yogjakarta: Pustaka Belajar , 2010 ), 1.

${ }^{3}$ Departemen Agama RI, Al-Qur'an dan Terjemahannya, Edisi Penyempuranaan, (Jakarta: PT. Syamil Cipta Media, 2019), 363.

${ }^{4}$ Yusuf Qandhawi, Berinteraksi dengan Al-Qur'an, ... 43.

${ }^{5}$ Ahsin WIjaya, Bimbingan Praktis Menghafal Al-Qur'an, (Jakarta: Bumi Aksara, 2000), 26.

${ }^{6}$ Wiwi Alawiyah Wahid, Cara Cepat Menghafal Al-Qur'an, (Jogjakarta: DIVA Press, 2014), 15.
} 
seharusnya tidak hanya menghafal dan mengingat lafadznya saja, melinkan harus diringi dengan pemahaman dan pengamalan yang sesuai. ${ }^{7}$

Para ulama menyepakati bahwa menghafal al-Qur'an bukanlah suatu ketentuan hukum yang harus dilakukan orang yang memeluk agama Islam. Dengan kata lain, hukum menghafal alQur'an adalah farhu kifayah yang artinya apabila sebagian orang melakukannya maka gugurlah dosa yang lain. ${ }^{8}$ Ulama selalu memberikan nasehat kepada para haafidz agar aktifitas menghafal al-Qur;an yang telah dia bangun agar tidak terputus jumlah tawattur di dalamnya, sehingga tidak dimungkinkan untuk penggantian dan pengubahan. Apabila dalam suatu kaum tidak ada yang melaksanakannya maka berdosalah semuanya, tetapi apabila ada diantara mereka yang melaksanakannya maka dosa yang lain akan dihapuskan. ${ }^{9}$

Salah satu keutamaan dalam menghafal al-Qur'an adalah mendapatkan ketenangan hati sebaimana aktivitas dalam menghafal al-Qur'an yang merupakan sarana untuk berdzikir atau mengingat Allah, adapun Allah menyebutkan dalam ayatnya yang berarti:

“(yaitu) orang-orang yang beriman dan hati mereka manjadi tenteram dengan mengingat Allah. Ingatlah, hanya dengan mengingati Allah-lah hati menjadi tenteram." (QS. Ar-Ra'd : 28). ${ }^{10}$

Dalam ayat diatas dijelaskan bahwa keutamaan yang sering dirasakan oleh para penghafal al-Qur'an adalah munculnya rasa kenyamanan d hati mereka, hal ini dikarenakan mereka lebih memilih untuk terus bersandar kepada Allah SWT daripada kepada sesama mereka. Allah juga melanjutkan dengan firman "Ingatlah hanya dengan mengingati Allah-lah hati menjadi tentram $\imath$ ', dengan kata lain seseorang pantas mendapat ketentraman jiwa saat ia diposisi selalu mengingat Allah SWT. ${ }^{11}$ Hal ini dikarenakan jiwa itu sendiri merupakan ciptakan Allah yang dianugerahkan kepada manusia, maka secara teori mereka akan mendapatkan kenyamanan apabila kembali ke fitrah awalnya atau kembali ke penciptanya. Sebagaimana pernyataan Ibn Sina yang dikutip Dr. Jarman Arroisi adalah, “....jiwa kekal tak berujung, tatapi ia memiliki

\footnotetext{
${ }^{7}$ Nur Aisyah, "Pengaruh Aktivitas Menghafal Al-Qur'an Terhadap Kecerdasan Spiritual Siswa Di Kelas Tahfidz SMP Negeri 10 Palembang”, Skripsi, Fakultas Ilmu Tarbiyah dan Keguruan Univeritas Islam Negeri (UIN) Raden Fatah Palembang, 2020, 3.

${ }^{8}$ Ahmad Salim Badwilan, Panduan Cepat Menghafal Al-Qur'an, (Jogjakarta: DIVA Press, 2009), 23.

${ }^{9}$ Abdurrab Nawabluddin dan Ma'rif, Teknik Menghafal Al-Qur'an, (Bandung: Sinar Baru Algensindo, 2005), 19.

${ }^{10}$ Departemen Agama RI, Al-Qur'an dan Terjemahannya........, 350.

${ }^{11}$ Abdullah Bin Muhammad Bin Abdurrahman Bin Ishaq Al-Sheikh, Tafsir Ibnu Katsir, (Bogor: Pustaka Imam Syafi'i, 2004), 500 .
} 
awal, yaitu diciptakan oleh Allah."12 Sehingga, jelas disimpulkan bahwa al-Qur'an sebagai sarana untuk bezikir dan mengingat kembali kepada Allah SWT. dengan menjalin hubungan kepada Allah maka hal ini akan mempengaruhi peningkatan kecerdasan spiritual seseorang.

Kecerdasan spiritual merupakan kecerdasan untuk menghadapi persoalan makna atau value, yaitu kecerdasan untuk menempatkan perilaku dan hidup dalam konteks makna yang lebih luas, kaya, kecerdasan ini untuk menilai bahwa tindakan atau jalan hidup seseorang lebih bermakna dibandingkan dengan yang lain. ${ }^{13}$ Konsep ini merupakan temuan ilmiah yang pertama kali digagas oleh Danah Zohar dan Ian Marshall. Dalam perkembangan seorang anak dari masa remaja menuju dewasa, kecerdasan spiritual dibutuhkan sebagai kesadaran untuk membina hubungan dengan orang lain secara etis, moral dan manusiawi. Sukdi juga memaparkan bahwa belakangan ini telah marak fenomena krisis manusia, krisis disini memiliki artian menyeluruh baik itu krisis intelektual maupun moral. Krisis moral hampir merambah ke seluruh aspek kehidupan, yang sebenarnya hal ini bersangkutan dengan krisis spiritual yang tertanam dalam diri manusia. ${ }^{14}$

Dengan kecerdasan spiritual, setiap individu akan memiliki visi dalam kehidupannya, artinya setiap individu akan mengetahui apa yang benar-benar memotivasi dirinya. Visi ini sebenarnya bertujuan untuk membentuk korelasi dengan sang Pencipta atau Allah SWT. Sehingga setiap individu akan merasakan keterkaitannya antara dirinya dengan Allah sehingga menciptakan keyakinan bahwa Allah adalah Maha segalanya. Korelasi tersebut tidak hanya berhenti kepada Tuhan melainkan juga kepada manusia atau sesama. Korelasi ini berbentuk seperti sikap-sikap positif dalam konteks kehidupan sosial, sikap empati terhadap sesama, saling menghormati satu sama lain serta membangun korelasi yang harmonis dengan memaafkan kesalahan orang lain. ${ }^{15}$ Dengan demikian, perlu dilakukannya penelitian terhadap potensi positif yang dihasilkan dari menghafal al-Qur'an. Oleh karena itu penulis ingin meneliti bagaimana kecerdasan spiritual itu tumbuh dan berkembang pada setiap individu penghafal al-Qur'an.

\footnotetext{
12 Jarman Arroisi, "Konsep Jiwa Perspektif Ibn SIna”, dalam Jurnal ISLAMICA, Vol. 13, No. 2, (Maret 2019 ), 340.

${ }^{13}$ Ary Gianjar Agustian, Rahasia Sukses Membangun Kecerdasan Emosi dan Spiritual (ESQ), (Jakarta: Arga Wijaya Persada, 2001), 46.

${ }^{14}$ Sukidi, Rahasia Sukses Hidup Bahagia Kecerdasan Spiritual: Mengapa SQ Lebih Penting daripada IQ dan EQ, (Jakarta: Gramedia Pustaka Utama, 2002), 4.

15 Siti A. Toyibah, Ambar Sulianti \& Tahrir, "Pengaruh Kecerdasan Spiritual Terhadap Kesejahteraan Psikologis Pada Mahasiswa Penghafal Alquran”, dalam Jurnal Psikologi Islam, Vol. 4, No. 2, (2017), 194.
} 


\section{Definisi Tahfidz Al-Qur'an}

Tahfidz Al-Qur'an merupakan gabungan dari kata tahfidz dan al-Qur'an. Tahfidz berasal dari bahasa arab yang mempunyai arti menjadi hafal dan menjaga hafalannya atau memelihara, menjaga, menghafal dengan baik. ${ }^{16}$ Secara etimologi, menghafal juga dapat diartikan sebagai mengingat. Dalam terminologi, istilah menghafal mempunyai arti sebagai, tindakan yang berusaha meresapkan ke dalam pikiran agar selalu ingat. Menghafal adalah suatu aktifitas menanamkan suatu materi di dalam ingatan, sehingga nantinya dapat diingat kembali secara harfiah, sesuai dengan materi yang asli. Menghafal merupakan proses mental untuk mencamkan dan menyimpan kesan-kesan, yang suatu waktu dapat diingat kembali ke alam sadar. ${ }^{17}$

Orang yang menghafal al-Qur'an lebih sering dikenal dengan istilah haafidz. Ibnu Mandzur sebagaimana dikutip oleh Abdulrab Nawabuddin mengartikan haafidz adalah orang yang berjaga - jaga, yaitu orang yang selalu menekuni pekerjaannya. ${ }^{18}$ Sementara dalam alQur'an al-hifdz sering diartikan dengan menahan diri dari hal-hal yang diharamkan Allah SWT. Dari seluruh pengertian tersebut dapat disimpulkan bahwa menghafal memiliki banyak pengertian. Banyaknya makna menghafal ini pada dasarnya terletak dalam konteks makna yang digunakan.

Pengertian al-Qur'an secara etimologis berarti bacaan atau yang dibaca, kata tersebut berasal dari bahasa arab yaitu qara' $a$ yang berarti membaca. ${ }^{19}$ Begitu juga hal yang diungkapkan oleh Quraish Shihab dalam buku Membumikan Al-Qur'an bahwa al-Quran biasa didefinisikan sebagai firman Allah yang disampaikan oleh Malikat Jibril as, sesuai redaksinya kepada nabi Muhammad Saw, dan diterima oleh umat secara tawatur. ${ }^{20}$

Dari definisi "menghafal" dan "al-Qur'an" tersebut dapat diambil dan dipahami sebuah pengertian yaitu menghafal al-Qur'an adalah suatu proses untuk menjaga dan memelihara alQur'an diluar kepala (dalam konteks mengingat) dengan baik dan benar dengan syarat dan tata cara yang telah ditentukan.

\footnotetext{
16 A. Warson Munawwir, Kamus Al-MMunawwir Arab - Indonesia, (Surabaya: Pustaka Progresif, 1997$), 301$.

17 Yusron Masduki, “Implikasi Psikologis Bagi Penghafal Al-Qur'an”, dalam Medina-Te, Vol. 18, No. 1, (Juni 2018), 22.

18 Abdulrab Nawabuddin, Kaifa Tahfadzul Qur'an, terj. Bambang Saiful Ma'arif, "Teknik Menghafal Al-Qur'an", (Bandung: Sinar Baru Algesindo, 1996), 25.

19 Mana’ul Quthan, Pembahasan Ilmu Al-Qur'an, (Jakarta: PT. Rineka Cipta, 1993), 11.

20 Quraish Shihab, Membumikan Al-Qur'an, (Bandung: Mizan, 2013), 50.
} 
Abdulrab Nawabuddin menjelaskan bahwa menghafal al-Qur'an berbeda dengan menghafal selain al-Qur'an. ${ }^{21}$ Perbedaan ini dikarenakan dua alasan. Pertama, menghafal alQur'an memiliki arti menghafal al-Qur'an secara keseluruhan baik itu dari konteks tektual maupun konteks makna. Kedua, menghafal al-Qur'an harus selalu konsisten dan senantiasa menjaga hafalan agar hafalannya tidak dilupakan. Sehingga orang yang sudah menghafal alQur'an ketika dia melupakan hafalannya baik itu ayat ataupun beberapa ayat, maka dia tidak berhak disebut sebagai haafidz. ${ }^{22}$

Pada akhirnya dari seluruh penjelasan diatas membuahkan kesimpulan bahwa menghafal al-Qur'an adalah suatu proses berupa kegiatan untuk menjaga, memelihara, dan melestarikan kemurnian al-Qur'an, hal ini dilakukan dengan mengingat ayat alqur'an baik itu berupa konteks tekstual maupun konteks makna. Maka tak jarang dijumpai beberapa sekelompok penghafal alQur'an yang terorganisir terkontrol dalam suatu sistem seperti pondok tahfidz dan sebagainya. Mereka yang benar-benar niat dalam menghafal al-Qur'an inilah yang harus disebut sebagai haafidz yang sebenarnya karena mereka melanjutkan perjuangan para pendahulu dalam memuliakan dan menjaga keaslian al-Qur'an. ${ }^{23}$

\section{Hikmah dalam Menghafal Al-Qur'an}

Dalam buku Hajar Al-Qur'an tanpa Nyantri karya Al-Kahil dibeberkan bahwa dengan menghafal al-Qur'an sama nilainya dengan membuka pintu-pintu kebaikan, karena dalam alQur'an tidak hanya dijelaskan mengenai kehidupan setelah mati melainkan tidak banyak ayat yang menjelaskan akan gaya kehidupan atau lifestyle di dunia sesuai syariat islami. Sehingga AlKahil menjelaskan bahwa dengan menghafal al-Qur'an seorang manusia tidak hanya akan menjalankan syariat dari Allah semata melainkan juga mengikuti arahan-Nya untuk hidup sesuai dengan syariat Islam. ${ }^{24}$

Kebanyakan manusia sekarang mengikuti gaya hidup para idolanya diluar sana, sementara mereka melupakan pesan dari Sang Kuasa untuk hidup sesuai syariat-Nya. Maka alQur'an disini bisa dijadikan media sebagai penghubung jiwa hambanya kepada Sang Pencipta yaitu Allah. Allah juga menjanjikan akan mengangkat derajat mereka yaitu para penghafal Al-

21 Abdulrab Nawabuddin, Kaifa Tahfadzul Qur'an,..5.

22 M. Ziyad Abbas, Metode Praktis Menghafal Alquran, (Jakarta: Firdaus, 1993), 29-30.

${ }^{23}$ Yudhi Fachrudin, "Pembinaan Tahfizh Al-Quran Di Pesantren Tahfizh Daarul Qur'an Tangerang” dalam Jurnal Koordinat, Vol. 16, No. 2, (Oktober 2017), 331.

24 Abdud Daim Al-Kahil, Hafal Al-Qur'an tanpa Nyantri, (Solo: Pustaka Arafah, 2010), 19. 
Qur'an sehingga kelak di akhirat al-Qur'an bisa menjadi saksi bisu kebaikan seseorang semasa hidupnya di dunia. ${ }^{25}$

Menghafal al-Qur'an juga mempunyai manfaat dalam akademis, pertama al-Qur'a n merupakan pengetahuan dasar bagi mereka para penuntut ilmu atau thalabal ilmi. Apabila ia menghafal al-Qur'an maka ia akan memberikan kontribusi yang sangat besar terhadap studinya, sebab al-Qur'an merupakan sumber pengetahuan. ${ }^{26}$ Selain sebagai sumber pengetahuan, alQur'an juga menjelaskan secara menyeluruh berbagai macam disiplin ilmu pengetahun baik itu material maupun immaterial, hal ini dijelaskan Dr. Jarman Arroisi dalam tulisannya yang berjudul Spiritual Healing dalam Tradisi Sufi. ${ }^{27}$ Kedua, orang yang menghafal al-Qur'an pasti akan meningkatkan kecerdasan akalnya dalam mengingat sesuatu, sehingga dalam masalah hafalan pelajaran para penghafal al-Qur'an rentan cepat dalam menghafal dibandingkan mereka selain penghafal al-Qur'an. Seringkali para penghafal al-Qur'an dikenal karena memiliki kecerdasan yang tinggi baik itu kecerdasan emosional, intelektual apalagi spiritual.

Al-Qur'an telah ditetapkan sebagai petunjuk utama umat muslim juga sebagai obat hati untuk mengusir beragam kegalauan manusia. ${ }^{28}$ Al-Qaradhawi juga menjelaskan teorinya berupa:

"Sementara penyembuhan dan pengobatan berbagai penyakit organ tubuh dengan alQuran tidak dikenal pada masa Nabawy dan sahabat, yang dilakukan para sahabat ialah Khoirul Anwar \& Mufti Hafiyana - Metode ODOA (One Day One Ayat) 184 hanya sekedar mengikuti tuntunan Nabi mereka yang disebut ruqyah dengan al-Quran..."29

Dengan demikian dapat disimpulkan bahwa al-Qur'an itu sendiri mendatangkan beribu manfaat sebagai media, maka orang yang menghafal al-Qur'an ialah orang yang mampu mengambil manfaat itu untuk digunakan sebaik-baiknya.

\footnotetext{
${ }^{25}$ Marliza Oktapian, “Tingkat Kecerdasan Spiritual dan Kemampuan Menghafal Al-Qur'an”, dalam Jurnal Tadzhib Al-Akhlak, Vol. 1, No. 5, (2020), 99.

26 Wiwi Alawiyah Wahid, Cara Cepat Menghafal Al-Qur'an),.... 145.

27 Jarman Arroisi, "Spiritual Healing dalam Tradisi Sufi", dalam Jurnal Tsaqafah, Vol. 14, No. 2, (November 2018), 332.

${ }^{28}$ Khoirul Anwar \& Mufti Hafiyana, "Implementasi Metode ODOA (One Day One Ayat) dalam Meningkatkan Kemampuan Menghafal Al-Quran", dalam Jurnal Pendidikan Islam Indonesia, Vol. 2, No. 2, (April 2018), 183. ${ }_{29}$ Al-Qaradhawi, Bagaimana Berinteraksi dengan Al-Quran, terj. Kathur Suhardi, (Jakarta Timur: Pustaka AlKautsar, 2000), 464.
} 


\section{Kecerdasan Spiritual}

Istilah spiritual berasal dari akar kata spirit yang berarti ruh. Kata ini berasal dari kata latin Spiritus yang berarti bernafas. Karena itu spiritual bisa diartikan sebagai ruh dan bernafas karena berfungsi sebagai energi kehidupan yang membuat seseorang menjadi hidup. Kemudian, istilah spiritual sering berfungsi sebagai sifat dari suatu bentuk kecerdasan selain kecerdasan intelektual dan emosional. ${ }^{30}$

Kecerdasan spiritual atau Spiritual Quotient merupakan kecerdasan yang mengangkat fungsi jiwa sebagai perangkat internal diri. Arti lainnya adalah kemampuan manusia untuk dapat mengenal dan memahami diri sepenuhnya sebagai makhluk spiritual maupun sebagai bagian dari alam semesta. Pada awalnya, kecerdasan spiritual pertama kali digagas dan ditemukan oleh Danah Zohar dan Ian Marshall.

Danah Zohar dalam bukunya yang berjudul SQ: Spiritual Intelligence, The Ultimate Intelligence, mengungkapkan bahwa kecerdasan spiritual adalah tingkat kecerdasan tertinggi yang mana memadukan kecerdasan intelektual dan kecerdasan emosional. Kecerdasan spiritual dinilai sebagai kecerdasan yang tertinggi karena kecerdasan spiritual ini mengandung seluruh aspek yang menjadikan manusia sebagai makhluk yang benar-benar utuh secara intelektual, sosial, dan spiritual. ${ }^{31}$

Ada beberapa alasan mengapa kecerdasan spiritual sebagai kecerdesan yang tertinggi. Pertama, segi perennial kecerdasan spiritual (SQ). Kecerdasan spiritual mampu mengungkapkan segi parenial (yang abadi, yang asasi, yang spiritual, yang fitrah). Segi parenial dalam bingkai kecerdasan spiritual tidak bisa dijelaskan melalui perspektif sains modern, hal ini dikarenakan sains modern hanya meneliti struktur kecerdasan sebatas apa yang dapat diverifikasi secara ilmiah dan empiris.

Kedua, mind-body-soul. Banyak ilmuwan yang sepakat bahwa manusia terdiri atas pikiran (mind), badan-tubuh (body), dan jiwa, spirit, roh (soul). Pada segi ini kecerdasan spiritual berfungsi dalam memfasilitasi dialog antara kecerdasan intelektual (IQ), kecerdasan emosional (EQ), dan antara keduanya.

\footnotetext{
30 Rahmat Aziz, “Tiga Jenis Kecerdasan dan Agresivitas Mahasiswa”, dalam Jurnal Psikologika, Vol. 11, No. 21, (Januari 2006), 70.

31 Danah Zohar dan Ian Marshall, SQ: Spiritual Intelligence, The Ultimate Intelligence, terj. Rahmani Astuti, Ahmad Najib Burhani, Ahmad Baiquni, Cet. Ke-11 (Bandung: Mizan, 2007), 5.
} 
Ketiga, kesehatan spiritual. Manusia belakangan ini sering terjangkiti berbagai penyakit spiritual dengan segala variasinya. Penyakit ini tidak dapat disembuhkan oleh kecerdasan intelektual dan emosional, melainkan harus menggunakan kecerdasan spiritual itu sendiri, karena kedua hal ini tidak menyentuh segi spiritual manusia sama sekali. Sebaliknya, Spiritual Quotient bukan hanya menyentuh segi spiritual melainkan lebih dari itu, dari menyentuh segi spiritual sampai dapat menyembuhkan kesehatan spiritual dengan berbagai pengalamannya.

Keempat, kedamaian spiritual. Setelah mencapai kesehatan spiritual, manusia dibimbing dan diarahkan untuk memperoleh kedamaian yang hakiki. Tidak seperti kedamaian yang dijanjikan oleh kecerdasan spiritual dan emosional. Alih-alih menciptakan kedamaian, justru mereka menjerumuskan manusia pada arogansi intelektual dan emosial; mulai dari krisis ekonomi, bahan bakar, lingkungan hidup, sosial, sampai politik. Sementara kecerdasan spiritual membimbing tuannya menggapai kedamaian melalui kecerdasan spiritual.

Kelima, kebahagiaan spiritual. Manusia modern sekarang ini tidak lagi puas akan kebahagian sebatas kebahagian material. Kebahagiaan material hanya membuat kehidupan mengalami berbagai persoalan eksistensial dan dapat memunculkan berbagai masalah kesehatan mental. Menurut Dr. Jarman Arroisi masalah kesehatan mental yang kerap muncul sebenarnya disebabkan adanya perubahan dalam kehidupan sosial masyarakat modern, ditandai dengan masyarakat mulai merindukan unsur spiritual dalam kehidupan yang mana hal ini sebelumnya dihilangkan. ${ }^{32}$ Oleh karena itu dengan kecerdasan spiritual terdapat sebuah ajaran tersendiri yang mana mengajak manusia untuk memaknai hidup secara lebih bermakna sehingga meraih kebahagiaan yang sejati, yakni kebahagiaan spiritual.

Keenam, kearifan spiritual. Segera setelah meraih kebahagiaan spiritual, kecerdasan spiritual mengarahkan manusia menuju tujuan ke ujung tangga, yaitu kearifan spiritual. Dengan kearifan spiritual seorang manusia bisa menjalani hidup secara arif, bijak seara spiritual seperti bersikap jujur, adil, toleran, terbuka, penuh cinta dan kasih sayang terhadap sesama. Hal ini yang sangat dibutuhkan oleh manusia kali ini, kearifan spiritual mampu mengatasi berbagai masalah yang ditimbulkan oleh IQ dan EQ seperti arogansi intelektual, rakus material, dan perbudakan emosional. ${ }^{33}$

\footnotetext{
32 Jarman Arroisi dan Erva Dewi Arqomi Puspita, "Soul Restoration in Islamic Tradition", dalam Jurnal Ushuluddin, Vol. 28, No. 2, (Juli-Desember 2020), 171.

${ }^{33}$ Sukidi, Rahasia Sukses Hidup Bahagia, Kecerdasan Spiritual: Mengapa SQ Lebih Penting Daripada IQ dan EQ, ...., 68-74.
} 
Ada aspek menadasar yang memerlukan penjelasan penting, yakni relasi antara SQ dan agama. Pada dasarnya kecerdasan spiritual tidak berhubungan dengan agama, tetapi memiliki hubungan erat dengan kejiwaan seseorang. Berbeda dengan pendapat diatas, Akhmad Muhaimin Azzet juga menegaskan bahwa agama juga memiliki hubungan erat dengan kejiwaan seseorang, Dalam buku Mengembangkan Kecerdasan Spiritual Bagi Anak Azzet menjelaskan bahwa ada sesuatu yang mendasar terkait dengan jiwa manusia, yakni keyakinan atau agama. Hal ini yang mendasari Azzet dalam berargumen bahwa agama memiliki hubungan dengan kejiwaan seseorang. Seseorang akan lebih mudah dalam mengembangkan kecerdasan spiritual dengan agama atau keyakinannya. ${ }^{34}$

Orang yang cerdas secara spiritual memiliki beberapa ciri, diantaranya; kemampuan bersikap fleksibel dalam menghadapi persoalan, tingkat kesadaran yang tinggi, kemampuan menghadapi penderitaan, kemampuan menghadapi rasa takut, kualitas hidup yang sesuai dengan visi dan nilai, enggan menyebabkan kerugian yang tidak perlu, cenderung melihat keterkaitan berbagai hal, hidup dengan penuh pengabdian dan tanggung jawab. ${ }^{35}$ Sebenarnya hal ini didukung oleh beberapa penjelasan dalam al-Qur'an, seperti terjemahan dalam Surat Ali Imron ayat 189-191 sebagai berikut.

"Milik Allahlah kerajaan langit dan bumi. Allah Mahakuasa atas segala sesuatu (189). Sesungguhnya dalam penciptaan langit dan bumi serta pergantian malam dan siang terdapat tanda-tanda (kebesaran Allah) bagi orang yang berakal, (190). (yaitu) orangorang yang mengingat Allah sambil berdiri, duduk, atau dalam keadaan berbaring, dan memikirkan tentang penciptaan langit dan bumi (seraya berkata), "Ya Tuhan kami, tidaklah Engkau menciptakan semua ini sia-sia. Mahasuci Engkau. Lindungilah kami dari azab neraka (191)." (QS. Ali Imron : 189-191). ${ }^{36}$

Dari ayat diatas dijelaskan ciri-ciri orang yang cerdas secara spiritual, seperti halnya orang yang beriman. Orang yang beriman adalah orang yang mempercayai adanya sesuatu yang transenden atau tidak terlihat oleh mata yang menguasai segalanya. Artinya al-Qur'an sangat mendorong umat Islam untuk selalu cerdas secara spiritual.

\footnotetext{
34 Akhmad Muhaimin Azzet, Mengembangkan Kecerdasan Spiritual Bagi Anak, (Yogyakarta: Kata Hati, 2010), 3839.

35 Ngainun Naim, “Kecerdasan Spiritual: Signifikansi dan Strategi Pengembangan”, dalam Jurnal Ta'allum, Vol. 2, No. 1 (Juni 2014), 46-47.

36 Departemen Agama RI, Al-Qur'an dan Terjemahannya........, 101-102.
} 


\section{Membangun Kecerdasan Spiritual dengan Tahfidz Al-Qur'an}

Bagi para penghafal al-Qur'an, mereka akan sering terinternalisasi nilai-nilai al-Qur'an maupun al-Hadist yang mana nilai-nili ini kemudia menjadi sumber potensial untuk membantu individu dalam menghafal ayat al-Qur'an. Oleh karena itu penghafal al-Qur'an dituntut untuk mampu melakukan regulasi diri dikarenakan proses menghafal membutuhkan kedisiplinan tinggi.

Menghafal al-Qur'an dimulai dengan proses membaca ayat berulang-ulang sehingga ayat tersebut tersimpan di memori dan dipahami maknanya. Sehingga sering penghafal al-Qur'an selalu siap dalam situasi dan kondisi dimanapun dan apapun, karena mereka selalu melantunkan ayat-ayat yang dihafalnya baik itu melalui lisan ataupun sekedar didalam hati. ${ }^{37}$ Dikarenakan seringnya membaca al-Qur'an para penghafal al-Qur'an lebih sering terlihat tentram dibandingkan dengan yang lainnya. Tidak sedikit dari mereka merasa nyaman dan tentram dikarenakan mereka mendapatkan berbagai macam rahmat dan hidayah dari Allah.

Dari Dr. Al-Qadhi, sebagaimana dikutip oleh Taslaman dalam bukunya Keajaiban AlQur'an beliau menerangkan hasil penelitiannya yang panjang di Klinik Besar Florida Amerika Serikat, berhasil membuktikan hanya dengan mendengarkan bacaan ayat-ayat al-Qur'an seorang Muslim dapat merasakan perubahan psikologis yang sangat besar. Perubahan seperti penurunan depresi, kesedihan, memperoleh ketenangan jiwa, menangkal berbagai macam penyakit, dan sebagainya. Hal ini merupakan pengaruh yang dirasakan oleh orang-orang yang menjadi objek penelitiannya. ${ }^{38}$

Orang yang konsisten dan rutin membaca al-Qur'an memiliki kemampuan kognitif yang luar biasa, karena kemampuan ini berpusat pada otak sementara para penghafal al-Qur'an selalu melatih otak mereka. Dengan kata lain penghafal al-Qur'an akan sering menumbuhkan dan mengembangkan kecerdasannya baik itu kecerdasan intelektual (IQ), kecerdasan emosional (EQ), kecerdasan spiritual (SQ). Pada akhirnya hal tersebut mampu mempengaruhi perilaku dan karakter individu karena kebiasaan tersebut tempimpan di dalam memori otaknya. ${ }^{39}$

Mencapai kematangan spiritual merupakan hal yang mudah didapatkan bagi para penghafal al-Qur'an. Dikarenakan mereka memiliki keimanan melebihi manusia pada umumnya,

\footnotetext{
37 Yusron Masduki, “Implikasi Psikologis Bagi Penghafal Al-Qur'an”, ...33.

38 Taslaman, Keajaiban Al-Qur'an, (Surabaya: Penerbit Sygma, 2014), 95.

39 Very Julianto, "The Effect of Reciting Holy Quran Toward Short Term Memory Ability", dalam Jurnal Psikologi Fakultas UGM, Vol. 38, No. 1, (Juni 2011), 143.
} 
mereka lebih sering bersama dengan ayat-ayat al-Qur'an. Bahkan mereka selalu merasa bahwa Allah SWT selalu bersama mereka dalam setiap aktivitas mereka. Karakteristik anak yang mempunyai kecerdasan spiritual dikarenakan menghafal al-qur'an dilihat dari beberapa indikator. Pertama, merasakan kehadiran Allah SWT. Mereka yang tidak hanya secara jasmani saja melainkan juga secara ruhani pasti selalu merasakan kehadiran Allah dimana saja mereka berada. Keyakinan kuat dari mereka timbul dikarenakan perasaan yang sangat dalam bahwa dirinya senantiasa berada dalam pengawasan Allah. ${ }^{40}$

Kedua, senang menolong orang lain. Manusia yang memilki kecerdasan spiritual yang tinggi akan senantiasa berbuat baik. Hal ini dibuktikan dengan sikapnya yang senang menolong orang lain. Karena dalam dirinya tumbuh rasa empati tinggi untuk dapat merasakan kondisi batin orang lain. ${ }^{41}$ Tiga cara yang sering dilakukan untuk menolong orang lain, yakni menolong dengan kata-kata, menolong dengan tenaga, dan menolong dengan barang. ${ }^{42}$ Seseorang yang memiliki kecerdasan spiritual tinggi pasti tidak akan meninggalkan orang lain yang membutuhkan bantuannya.

Ketiga, bertanggung jawab. Dalam Islam, pertanggung jawaban merupakan salah satu dasar dari keyakinan agama. Setiap manusia akan mempertanggung jawabkan segala hal yang dilakukannya selama masa hidupnya di dunia di akhirat kelak. Tidak hanya itu setiap individu juga diwajibkan untuk bertanggung jawab terhadap apa yang dimilikinya. ${ }^{43}$

Keempat, jujur. Kejujuran merupakan tiang penopang segala persoalan hidup. Salah satu dimensi kecerdasan spiritual terletak pada nilai kejujuran merupakan ciri khas dari kepribadian orang-orang yang mulia. Kejujuran merupakan komponen rohani yang membentuk manusia untuk melakukan berbagai perbuatan yang terpuji. Sehingga bagi mereka yang memiliki kecerdasan spiritual tinggi jujur merupakan kebiasaan baik bagi mereka. ${ }^{44}$

Kelima, disiplin dan sungguh-sungguh. Menghargai waktu dan bersikap sungguhsungguh merupakan ciri-ciri seorang Muslim yang memiliki kecerdasan spiritual tinggi. Bagi mereka disiplin timbul dan muncul dari dalam jiwa karena adanya dorongan untuk menaati tata

\footnotetext{
40 Toto Tasmara, Kecerdasan Ruhaniah, (Transedental Intelligence), Membentuk Kepribadian yang Bertanggung Jawab, Profesional dan Berakhlak, (Jakarta: Gema Insani, 2001), 14.

41 Toto Tasmara, Kecerdasan Ruhaniah,.... 30.

42 Akhmad Muhaimin Azzet, Mengembangkan Kecerdasan Spiritual Bagi Anak, ...49.

43 Syahmuharnis dan Harry Sidharta, Trancendental Quotient: Kecerdasan Diri Terbaik, (Jakarta: Republika, 2006), 176.

44 Syahmuharnis dan Harry Sidharta, Trancendental Quotient: Kecerdasan Diri Terbaik,.... 172.
} 
tertib. Maka disiplin bisa dijadikan pengatur dalam kehidupan seseorang baik itu secara individual maupun kelompok. ${ }^{45}$

Dengan demikian menghafal al-Qur'an tidak hanya bisa mentrentamkan hati seseorang, menjauhkan dari segala permasalahan. Tetapi juga dapat membantu dalam mengembangkan kecerdasan spiritual seseorang. Menghafal al-Qur'an membantu perkembangan kecerdasan spiritual melalui beberapa aspek. Seperti yang disebutkan sebelumnya, dengan menghafal alQur'an setiap inividu berpotensi dalam membangkitkan kecerdasan spiritualnya seperti, merasakan kehadiran Allah, senang menolong orang lain dan berbuat baik, selalu bertanggung jawab, jujur dalam setiap perkataan, disiplin dan bersungguh-sungguh.

\section{Kesimpulan}

Tahfidz al-Qur'an merupakan gabungan kata dari tahfidz dan al-Qur'an itu sendiri. Setiap kata mengandung makna dan arti yang berbeda. Kata tahfidz sendiri berasal dari bahasa arab yaitu hafadza, yang mempunyai arti menghafal, menjaga hafalannya dan memelihara dengan baik. Secara terminology, istilah menghafal memiliki arti suatu proses tindakan yang berusaha menanamkan sebuah memori ke dalam ingatan, memori apapun itu. Sementara al-Qur'an secara bahasa juga berasal dari bahasa arab yaitu qara'a yang berarti membaca. Dalam istilah definisi al-Qur'an sering di jelaskan sebagai kitabnya umat muslim yang diturunkan oleh Allah kepada perantaranya yaitu nabi Muhammad. Sehingga dapat digabungkan kedua kata yang berbeda berupa tahfidz dan al-Qur'an yang kemudian menjadi tahfidz al-Qur'an. Kalau tadi menghafal itu suatu proses mengingat segala memori berbeda halnya dengan tahfidz. Tahfidz ini merupakan istilah yang kerap digunakan kepada mereka yang menghafal ayat-ayat dalam al-Qur'an makanya kata tahfidz ini sering kali dibarengi dengan sebuah objek yaitu al-Qur'an itu sendiri.

Menghafal al-Qur'an memberi seorang manusia banyak manfaat tersendiri, baik itu di dunia maupun di kehidupan akhir yaitu di akhirat. Banyaknya ulama maupun kiyai yang menjelaskan berbagai manfaat, hikmah dan keutamaan mereka yang menghafal al-Qur'an. Salah satu manfaat menghafal al-Qur'an di dunia adalah terciptanya pola hidup yang sesuai dengan ajaran Rosulullah, sehingga menciptakan lingkungan yang damai. Keutamaan menghafal alQur'an tidak hanya sampai disitu, bahkan bagi mereka yang memiliki niat kuat dalam menghafal al-Qur'an mereka dapat merasakan kelebihannya dalam hal akademis. Ingatan seseorang

\footnotetext{
${ }^{45}$ Syahmuharnis dan Harry Sidharta, Trancendental Quotient: Kecerdasan Diri Terbaik,.... 178.
} 
penghafal al-Qur'an cukup kuat karena kecerdasan emosional, intelektual dan spiritualnya sudah terlatih, maka dari itu dalam hal pembelajaran di akademik orang penghafal al-Qur'an sering kali memiliki ingatan lebih dibandingkan teman-temannya. Al-Qur'an juga bisa menjadi saksi bisu perbuatan baik seorang hamba akan perkerjaannya didunia. Dengan adanya al-Qur'an ini bisa jadi sebagai pelindung manusia juga kelak di alam kubur nanti maupun di akhirat.

Membahas tentang menghafal al-Qur'an apa sebenarnya hal unik dari para penghafal alQur'an. Penghafal al-Qur'an seringkali mengembangkan kecerdasan spiritual atau Spirtual Quotient. Kecerdasan ini merupakan kecerdasan yang mengangkat fungsi jiwa sebagai perangkat internal diri. Arti lainnya adalah kemampuan manusia untuk dapat mengenal dan memahami diri sepenuhnya sebagai makhluk spiritual maupun sebagai bagian dari alam semesta. Orang yang cerdas secara emosional ataupun cerdas secara intelektual belum tentu dia cerdas secara spiritual, sementara mereka yang cerdas secara spiritual sudah dapat dipastikan bahwa mereka juga memiliki kecerdasan emosional dan intelektual. Dalam al-Qur'an kecerdasan spiritual seseorang ditandai dengan tingkat keimanan seseorang, mengapa demikian?. Dijelaskan demikian karena orang yang beriman itu dapat mempercayai hal-hal yang tidak dapat dilihat oleh mata, tidak dapat dipikirkan oleh akal, tidak dapat disentuh oleh kulit maka bisa dikatakan mereka mempercayai sesuatu yang transenden. Hal yang tidak tertulis saja mereka dapat percayai dan yakini apalagi segala sesuatu yang berkaitan dengan hal duniawi, inilah yang menjadi tolak ukur kecerdasan spiritual dalam al-Qur'an.

Kecerdasan spiritual para pengafal al-Qur'an dapat tumbu dan berkembang dengan pesat dibandingkan yang lainnya. Secara logika, para penghafal al-Qur'an sering terinternalisasi oleh nilai-nilai al-Qur'an maupun al-Hadist Rosulullah. Oleh karena itu psikologis seorang penghafal al-Qur'an sering kali dibangun dalam kedisiplinan yang tinggi, hal ini juga dapat memicu perkembangan dan pertumbuhan kecerdasan spiritual seseorang. Anak penghafal al-Qur'an cenderung memiliki karakteristik sendiri seperti; merasakan kehadiran Allah, senang menolong orang lain, bertanggung jawab, jujur, disiplin dan sungguh-sungguh. Dengan demikian dapat disimpulkan bahwa salah satu cara terefektif dalam menumbuhkan kecerdasan spiritual seseorang adalah melalui program tahfidz al-Qur'an sebab dengan tahfidz al-Qur'an seseorang akan sering menjumpai ayat-ayat al-Qur'an yang lambat laun akan membangun sebuah kesadaran didalam memori dan menumbuhkan kecerdasan spiritual sendiri. Setelah tumbuhnya kecerdasan spiritual maka kecerdasan emosional dan intelektual akan muncul secara sendirinya. 


\section{Daftar Pustaka}

Abbas, M. Ziyad. Metode Praktis Menghafal Al-Qur'an. (Jakarta: Firdaus, 1993).

Agustian, Ary Gianjar. Rahasia Sukses Membangun Kecerdasan Emosional dan Spiritual (ESQ). (Jakarta: Arga Wijaya Persada, 2001).

Aisyah, Nur. 'Pengaruh Aktivitas Menghafal Al-Qur'an Terhadap Kecerdasan Spiritual Siswa Di Kelas Tahfidz SMP Negeri 10 Palembang.”, Skripsi, Universitas Islam Negeri (UIN) Raden Fatah Palembang, (2020).

Al-Kahlil, Abdud Dalim. Hafal Al-Qur'an tanpa Nyantri. (Solo: Pustaka Arab, 2010).

Al-Qaradhawi. Bagaimana Berinteraksi dengan Al-Quran. Diterjemahkan oleh Kathur Suhardi. (Jakarta: Pustaka Al-Kautsar, 2000).

Al-Sheikh, Abdullah Bin Muhammad Bin Abdurrahman Bin Ishaq. Tafsir Ibnu Katsir. (Bogor: Pustaka Imam, 2004).

Anwar, Khoirul, dan Mufti Hafiyana. "Implementasi Metode ODOA (One Day One Ayat) dalam Meningkatkan Kemampuan Menghafal Al-Quran.”, dalam Pendidikan Islam Indonesia, Vol. 2, No. 2, (2018).

Arroisi, Jarman. “Konsep Jiwa Perspektif Ibn Sina.”, dalam ISLAMICA, Vol. 13, No. 2 (2019).

Arroisi, Jarman. “Spiritual Healing dalam Tradisi Sufi.”, dalam Tsaqafah, Vol. 14, No. 2 (2018).

Arroisi, Jarman, dan Erva Dewi Arqomi Puspita. "Soul Restoration in Islamic Tradition.”, dalam Ushuluddin, Vol. 28, No. 2 (2020).

Aziz, Rahmat. "Tiga Jenis Kecerdasan dan Agresivitas Mahasiswa.”, dalam Psikologika, Vol. 11, No. 21 (2006).

Azzet, Akhmad Muhaimin. Membangun Kecerdasan Spiritual Bagi Anak. (Yogyakarta: Kata Hati, 2010).

Badwilan, Ahmad Salim. Panduan Cepat Menghafal Al-Qur'an. (Yogyakarta: DIVA Press, 2009).

Chairoani, Lisya, dan Subandi. Psikologi Santri Menghafal Al-Qur'an: Peran Regulasi Diri. (Yogyakarta: Pustaka Belajar, 2010).

Fachruddin, Yudhi. 'Pembinaan Tahfizh Al-Quran Di Pesantren Tahfizh Daarul Qur'an Tangerang.", dalam Koordinat, Vol. 16, No. 2 (2017). 
Julianto, Very. "The Effect of Reciting Holy Quran Toward Short Term Memory Ability.", dalam Psikologi Fakultas UGM, Vol. 38, No. 1 (2011).

Masduki, Yusron. “Implikasi Psikologi Bagi Penghafal Al-Qur'an.”, dalam Medina-Te, Vol. 18, No. 1 (2018).

Munawwir, A. Warson. Kamus Al-Munawwir Arab-Indonesia. (Surabaya: Pustaka Prograsif, 1997).

Naim, Ngainun. "Kecerdasan Spiritual : Signifikansi dan Strategi Pengembangan.", dalam Ta'allum, Vol. 2, No. 1 (2014).

Nawabluddin, Abdurrab dan Ma'arif. Tekhnik Menghafal Al-Qur'an. (Bandung: Sinar Baru Algensindo, 2005).

Nawabuddin, Abdullah. Kaifa Tahfidzul Qur'an. Diterjemahkan oleh Bambang Saiful Ma'arif. (Bandung: Sinar Baru Algensindo, 1996).

Oktapian, Marliza. “Tingkat Kecerdasan Spiritual dan Kemampuan Menghafal Al-Qur'an.”, dalam Tadzhib Al-Akhlak, Vol. 1, No. 5 (2020).

Qandhawi, Yusuf. Berinteraksi dengan Al-Qur'an. (Jakarta: Gema Insani Press, 1999).

Quthan, Mana'ul. Pembahasan Ilmu Al-Qur'an. (Jakarta: PT. Rineka Cipta, 1993).

RI, Departemen Agama. Al-Qur'an dan Terjemahannya. Edisi Penyempurn. (Jakarta: PT. Syamil Cipta Media, 2019).

Shihab, Quraish. Membumikan Al-Qur'an. (Bandung: Mizan, 2013).

Sukidi. Rahasia Sukses Hidup Bahagia Kecerdasan Spiritual : Mengapa SQ Lebih Penting daripada IQ dan EQ. (Jakarta: Gramedia Pustaka Utama, 2002).

Syahmuhamis, dan Harry Sidharta. Transedental Quotient: Kecerdasan Diri Terbaik. (Jakarta: Republika, 2006).

Taslaman. Keajaiban Al-Qur'an. (Surabaya: Penerbit Sygma, 2014).

Tasmara, Toto. Kecerdasan Ruhaniah (Transedental Intelligence), Membentuk Kepribadian yang Bertanggung Jawab. (Jakarta: Gema Insani Press, 2001).

Toyibah, Siti A., Ambar Sulianti, dan Tahrir. "Pengaruh Kecerdasan Spiritual Terhadap Kesejahteraan Psikologis Pada Mahasiswa Penghafal Alquran.” Psikologi Islam, Vol. 4, No. 2 (2017).

Wahid, Wiwi Alawiyah. Cara Cepat Menghafal Al-Qur'an. (Yogyakarta: DIVA Press, 2014). 
Wijaya, Ahsin. Bimbingan Praktis Menghafal Al-Qur'an. (Jakarta: Bumi Aksara, 2000).

Zohar, Danah, dan Ian Marshall. SQ: Spiritual Intelligence, The Ultimate Intelligence. Diterjemahkan oleh Rahmani Astuti, Ahmad Najib Burhani, dan Ahmad Baiquni. 11 ed. (Bandung: Mizan, 2007). 